\title{
Financial Planning: Applications to Business Startups "Jamu Partnership" in Indonesia
}

\section{Noer Rachman Chakim ${ }^{1}$, Rhian Indradewa ${ }^{2}$, Tantri Yanuar Rahmat $\mathrm{Syah}^{3}$, Diana Fajarwati ${ }^{4}$}

1,2,3,4 Department Management, Faculty Economic and Business, Esa Unggul University, Jakarta - Indonesia

\begin{abstract}
Background - PT OAM is a startup company in the field of jamu partnerships in Indonesia. Jamu itself is a traditional health drink product originating from Indonesia. As a startup company in running the jamu partnership business, of course PT OAM really needs to carry out financial analysis by calculating and analyzing existing parameters. The data obtained from this analysis will be able to assist company management in making strategic decisions both now and in the future. One of the analyzes is an investment feasibility analysis. In addition, a method to assess the feasibility of an investment is also needed in identifying the prospect of an investment plan. The prospect of an investment plan can be used as a basis for making a decision to accept or reject an unprofitable investment. Financial planning is one of the important aspects for the sustainability of PT OAM jamu partnership business.

Method - Using financial plan framework Result - This financial analysis can help companies in financial decisions.
\end{abstract}

Keywords: Financial Plan, Startups, Jamu Partnership, Business Opportunity, Indonesia.

\section{INTRODUCTION}

PT OAM is a startup company in the field of jamu partnerships in Indonesia. Jamu itself is a traditional health drink product originating from Indonesia. The jamu partnership business system was chosen by PT OAM because it saw the desire for entrepreneurship which continues to increase every year in Indonesia, so the potential for this B2B market is very large. In addition, jamu products were chosen because $73 \%$ of people in Indonesia make health as the most important issue. As a business startup, PT OAM is in direct need of capital. Management capital directly affects the profitability and liquidity position of the company also confirms important role of capital (Kusuma et al., 2021). In addition to capital, financial analysis is also needed to ensure that capital can be used properly and appropriately. PT OAM's financial analysis is carried out by calculating and analyzing existing parameters (Kwarti et al., 2019). The data obtained from this analysis will be able to assist company management in making strategic decisions both now and in the future. This is because financial analysis can help answer important questions such as (1) Should the property be purchased, (2) How should it be financed, (3) How long should it be held, and How risky is the investment (Oprea, 2010). Investment decisions themselves are generally based on investor considerations of the expected returns and the risks that will be faced. The results of the financial analysis will be taken into consideration for investors in making decisions about their investment plans (Gansel, 2005). In addition, a method to assess the feasibility of an investment is also needed in identifying the prospect of an investment plan. The prospect of an investment plan can be used as a basis for making a decision to accept or reject an 
Noer Rachman Chakim et.al. Financial planning: applications to business startups "jamu partnership" in Indonesia.

unprofitable investment (David, 2012). Financial planning is one of the important aspects for the sustainability of PT OAM jamu partnership business.

\section{MATERIALS AND METHODS}

As a startup company, PT OAM has challenges in creating superior value for its customers and improving financial performance (Dror, S., \& Barad, 2006). So that the company's financial objective are prepared to answer these two things and are prepared in the short-term, mid-term and long-term objectives as shown in Table 2.1 below.

\begin{tabular}{|c|c|l|}
\hline \multicolumn{2}{|c|}{ Table 2.1 Financial Objectives. } \\
\hline $\begin{array}{c}\text { Category } \\
\text { Short } \\
\text { Term }\end{array}$ & 1 & $\begin{array}{l}\text { Financial Objectives } \\
\text { establishment of the company }\end{array}$ \\
\hline $\begin{array}{c}\text { Y.O to }< \\
\text { Y.1 }\end{array}$ & 2 & $\begin{array}{l}\text { Funding for employee costs, } \\
\text { marketing costs and initial } \\
\text { operational costs }\end{array}$ \\
\hline $\begin{array}{c}\text { Medium } \\
\text { Term }\end{array}$ & 1 & Revenue Optimization \\
\hline $\begin{array}{c}\text { Y.1 to }< \\
\text { Y.2 }\end{array}$ & 2 & $\begin{array}{l}\text { Ensure the availability of funds for } \\
\text { company operations }\end{array}$ \\
\hline $\begin{array}{c}\text { Long } \\
\text { Term }\end{array}$ & 1 & $\begin{array}{l}\text { Maximum Asset Management and } \\
\text { Utilization }\end{array}$ \\
\hline Y $>2$ & 2 & $\begin{array}{l}\text { Increase the trust of parties with an } \\
\text { interest in financial-related } \\
\text { companies }\end{array}$ \\
\hline \multicolumn{2}{|c|}{\begin{tabular}{c} 
Source: Author, 2021. \\
\hline
\end{tabular}}
\end{tabular}

On the other hand, PT OAM investment feasibility analysis also follows a financial planning framework consisting of five elements of financial planning regarding sales, related costs, investments, capital requirements, and financing, resulting in three components: income statement planning, balance sheet, and cash flow statement (Gansel, 2005). In PT OAM uses pre-prepared calculation parameters to the measure investment feasibility (Prihambodo et al., 2020). PT OAM financial analysis includes (1) financial element planning (ARR, ROI, NPV, Payback Period and Internal Rate of Return) (2) financial projection (3) financial feasibility analysis, and (4) financial performance analysis, which will be explained in the next discussion section. PT OAM financial plan framework is shown in Figure 2.1 below.

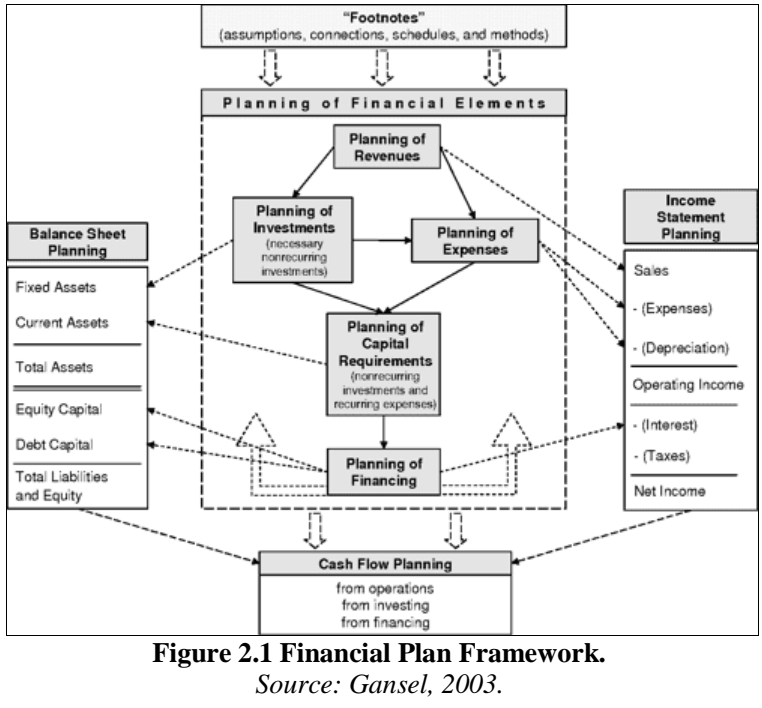

\section{DISCUSSION}

Based on the description of the financial analysis plan above, the following are the results of the discussion of PT OAM financial analysis.

\subsection{Financial Element Planning}

PT OAM's Financial Element Planning takes into account 3 (three) main functions, namely the Marketing Function, Operational Function and Human Resources Function. Revenue planning is calculated according to the annual target where the revenue estimate is based on 2 (two) sources, namely the sales target of the jamu partnership package and product sales. Marketing costs consist of advertising costs, sales commissions, costs for marketing activities such as workshops, webinars, competition prizes, product samples and website subscriptions. Pre-operational costs consist of building renovation costs, licensing fees, cafe sample fees, and consultant fees. Capital Expenditure (CAPEX) consists of the cost of purchasing operational vehicles, the cost of purchasing assets such as office equipment, training equipment, and Information Technology equipment. Operational Costs (OPEX) consist of electricity, water, communication costs, office supplies, research and development, office and warehouse rental costs, and other operational costs. Human Resources Management costs consist of salaries and benefits, health and employment insurance costs, recruitment 
Noer Rachman Chakim et.al. Financial planning: applications to business startups "jamu partnership" in Indonesia.

costs for prospective employees, training costs and employee development costs.

The decision to invest in the jamu partnership business and the sale of jamu products is of course taking into account the public's interest in this business and the rate of return on the funds invested.

As a startup, PT OAM has carefully calculated the development of this business going forward because of course this business has risks as a result of the lack of investor interest in investing and the lack of public awareness in capturing this business opportunity. However, considering the current conditions where people are starting to like a healthy lifestyle, of course, PT OAM's biggest hope is that this business can be accepted by the community and develop quickly.

The authorized capital of PT OAM is Rp. 5,800,000,000.00 (five billion eight hundred million rupiah) which consists of the capital participation of 4 (four) founders of $40 \%$ (sixty) percent. Part of capital will be sought from other investors who are interested in investing their shares. It is expected that there will be an incoming investment from Angel Investors amounting to $60 \%$ (forty) percent.

\subsection{Financial Projection}

Financial Projections consist of Projected Income Statement, Balance Sheet and Cash Flow Statement.

\begin{tabular}{|c|c|c|c|c|c|}
\hline Keterangan & Year 1 & Year 2 & Year 3 & Year 3 & Year 4 \\
\hline Revenue & $2,261,460$ & $10,660,651$ & $22,662,583$ & $47,188,838$ & $77,643,378$ \\
\hline Cost of Goods sold & $1,130,730$ & $5,870,925$ & $12,538,787$ & $26,023,240$ & $42,949,230$ \\
\hline Gross Profit & $1,130,730$ & $4,789,726$ & $10,123,796$ & $21,165,598$ & $34,694,148$ \\
\hline \multicolumn{6}{|l|}{ Expenses: } \\
\hline Employees expenses & $1,095,775$ & $1,668,677$ & $1,967,069$ & $2,125,016$ & $2,284,898$ \\
\hline Marketing Expenses & 211,729 & $1,100,041$ & $2,306,584$ & $4,845,654$ & $8,069,906$ \\
\hline Operation Expenses & 475,252 & 932,468 & $1,214,442$ & $1,757,530$ & $2,427,162$ \\
\hline Depreciation Expense & 106,368 & 188,147 & 188,303 & 188,658 & 194,911 \\
\hline Total Expenses & $1,889,124$ & $3,889,333$ & $5,676,398$ & $8,916,857$ & $12,976,877$ \\
\hline Earning before tax & $(758,394)$ & 900,393 & $4,447,398$ & $12,248,741$ & $21,717,271$ \\
\hline Tax & 0 & 0 & 0 & 907,120 & $2,468,270$ \\
\hline Tax rate & $22 \%$ & $22 \%$ & $20 \%$ & $20 \%$ & $20 \%$ \\
\hline Earning after tax & $(758,394)$ & 900,393 & $4,447,398$ & $11,341,621$ & $19,249,000$ \\
\hline Dividend $50 \%$ & 0 & 0 & 900,393 & $4,447,398$ & $11,341,621$ \\
\hline Retain Earning & $(758,394)$ & 900,393 & $3,547,005$ & $6,894,224$ & $7,907,379$ \\
\hline
\end{tabular}

Table 3.2 Balance Sheet (Rp. 000)

\begin{tabular}{|c|c|c|c|c|c|}
\hline Category & Year 1 & Year 2 & Year 3 & Year 4 & Year 5 \\
\hline \multicolumn{6}{|l|}{ ASSETS } \\
\hline Current Assets & $5,585,084$ & $6,773,489$ & $11,558,410$ & $20,577,836$ & $31,895,502$ \\
\hline Fised Assets & 508,703 & 849,440 & 667,414 & 485,525 & 325,454 \\
\hline Total Assets & $6,093,786$ & $7,622,929$ & $12,225,824$ & $21,063,361$ & $32,220,956$ \\
\hline \multicolumn{6}{|l|}{ LIABILTIES } \\
\hline Sub total Current Liabilities & $1,052,180$ & $1,680,930$ & $2,736,820$ & $4,680,133$ & $7,930,349$ \\
\hline \multicolumn{6}{|l|}{ EQUTTY } \\
\hline Equity & $5,800,000$ & $5,800,000$ & $5,800,000$ & $5,800,000$ & $5,800,000$ \\
\hline Retain Earning & $(758,394)$ & 141,999 & $3,689,004$ & $10,583,228$ & $18,490,607$ \\
\hline Sub total Equity & $5,041,606$ & $5,941,999$ & $9,489,004$ & $16,383,228$ & $24,290,607$ \\
\hline Total Liabilities and Equity & $6,093,786$ & $7,622,929$ & $12,225,824$ & $21,063,361$ & $32,220,956$ \\
\hline
\end{tabular}

Table 3.3 Cash Flow Statement (Rp. 000)

\begin{tabular}{|l|r|r|r|r|r|}
\hline \multicolumn{1}{|c|}{ Description } & Year 1 & Year 2 & Year 3 & Year 4 & Year 5 \\
\hline OPERATING ACTIVITIES & & & & & \\
\hline Receipt from Customers & $(293,292)$ & $(229,254)$ & $(204,948)$ & $(346,947)$ & $(265,707)$ \\
\hline Other Current Assets & 0 & 0 & 0 & 0 & 0 \\
\hline Payment to Supplier & 53,470 & 375,260 & $1,072,345$ & $2,103,820$ & $3,433,935$ \\
\hline Other short term debt & 0 & 0 & 0 & 0 & 0 \\
\hline Other income & 0 & 0 & 0 & 0 & 0 \\
\hline Operational expenses & 12,825 & 143,713 & 325,738 & 507,764 & 689,790 \\
\hline Net cash from operating activities & $(226,997)$ & 289,719 & $1,193,135$ & $2,264,637$ & $3,858,018$ \\
\hline INVESTMENT ACTIVITIES & & & & & \\
\hline Asset Acquisition/Sales & 0 & 0 & 0 & 0 & 0 \\
\hline Other investment activities & 0 & 0 & 0 & 0 & 0 \\
\hline Net cash from investing activities & 0 & 0 & 0 & 0 & 0 \\
\hline FUNDING ACTIVITIES & & & & & \\
\hline Loan payments/receipts & 0 & 0 & 0 & 0 & 0 \\
\hline Equity/Capital & 127,289 & 159,024 & 390,981 & 702,983 & 791,440 \\
\hline Net cash from Funding Activities & 127,289 & 159,024 & 390,981 & 702,983 & 791,440 \\
\hline Increase(Decrease) Cash & $(99,708)$ & 448,743 & $1,584,116$ & $2,967,620$ & $4,649,457$ \\
\hline Initial Cash Balance & $3,555,952$ & $2,337,610$ & $2,521,756$ & $2,067,567$ & $1,911,861$ \\
\hline Final Cash Balance & $3,456,244$ & $2,786,352$ & $4,105,872$ & $5,035,188$ & $6,561,318$ \\
\hline
\end{tabular}

\subsection{Financial Feasibility Analysis}

In business planning PT OAM seriously considers whether the investment to be made will generate profits. For this reason, it is necessary to analyze the feasibility of investments with several methods, namely Average of Return (ARR), Return on Investment (ROI), Net Present Value (NPV), Break Even Point (BEP), Payback Period (PP), and Internal Rate Of Return. (IRR).

Following are the results of the measurement of PT OAM's investment feasibility analysis:

Table 3.4 Investment feasibility analysis (Rp. 000)

\begin{tabular}{|l|r|r|r|r|r|}
\hline \multicolumn{1}{|c|}{ Description } & \multicolumn{1}{c|}{ Year 1 } & \multicolumn{1}{c|}{ Year 2 } & \multicolumn{1}{c|}{ Year 3 } & \multicolumn{1}{c|}{ Year 4 } & \multicolumn{1}{c|}{ Year 5 } \\
\hline Average Rate of Return (ARR) & $-13.08 \%$ & $7.76 \%$ & $25.56 \%$ & $52.80 \%$ & $74.89 \%$ \\
\hline Return On Investment (ROI) & $-61.01 \%$ & $83.80 \%$ & $290.73 \%$ & $713.60 \%$ & $1238.68 \%$ \\
\hline Net Present Value (NPV)1 = 10\% & $(689,449)$ & 744,126 & $3,341,396$ & $7,746,480$ & $11,952,115$ \\
\hline Net Present Value (NPV)2 = 45\% & $(489,286)$ & 744,126 & $1,194,293$ & $1,964,936$ & $2,151,541$ \\
\hline Payback Period (PP) & -8.90 & 5.33 & 1.25 & 0.50 & 0.30 \\
\hline Internal Rate of Return (IRR) & \multicolumn{5}{|c|}{$34.16 \%$} \\
\hline
\end{tabular}


From the measurement results with all these methods, it shows that the business that will be run by PT OAM is feasible to be done.

\subsection{Financial Performance Analysis}

Financial Performance is a description of the company's financial condition in a certain period, both regarding aspects of receiving funds and using funds which are usually measured by indicators of capital adequacy, liquidity and profitability. This analysis is also to find out whether the company has used the financial implementation rules properly and correctly.

Table 3.5 Financial Performance Analysis (Rp. 000)

\begin{tabular}{|l|c|c|c|c|c|}
\hline \multicolumn{1}{|c|}{ Description } & Year 1 & Year 2 & Year 3 & Year 4 & Year 5 \\
\hline Rasio Likuiditas & & & & & \\
\hline Current Ratio & $530.81 \%$ & $402.96 \%$ & $422.33 \%$ & $439.68 \%$ & $402.20 \%$ \\
\hline Quick Ratio & $451.75 \%$ & $294.92 \%$ & $297.14 \%$ & $286.28 \%$ & $251.96 \%$ \\
\hline Cash Ratio & $328.48 \%$ & $165.76 \%$ & $150.02 \%$ & $107.59 \%$ & $82.74 \%$ \\
\hline Rasio Solvabilitas/Leverage & & & & & \\
\hline Debt to Asset Rasio & $17.27 \%$ & $22.05 \%$ & $22.39 \%$ & $22.22 \%$ & $24.61 \%$ \\
\hline Debt to Equity Ratio & $20.87 \%$ & $28.29 \%$ & $28.84 \%$ & $28.57 \%$ & $32.65 \%$ \\
\hline Rasio Profitabilitas & & & & & \\
\hline Profit Margin on Sales & $-33.54 \%$ & $8.45 \%$ & $19.62 \%$ & $24.03 \%$ & $24.79 \%$ \\
\hline \multicolumn{5}{|l|}{ Source: Author, 2021. } & \\
\end{tabular}

From the calculation results of the liquidity ratio, it is known that the analysis of Current Ratio, Quick Ratio and Cash Ratio from year 1 to year 5 shows PT OAM has the ability to pay off its short-term debt. The result of the solvency ratio using the Debt to Asset Ratio and Debt to Equity Ratio methods, it is known that the company has the ability to pay off short-term and long-term debt from year 1 to year 5 with very good results, with a ratio of $17,27 \%$ $32,65 \%$. According to the results of the profitability analysis, it is known that the company's Profit Margin on Sales continues to show improvement from $(3,54 \%)$ in the first year to $24,79 \%$ in the 5 th year.

\section{CONCLUSION}

The jamu partnership business model in Indonesia is still very small. Starting from the desire for entrepreneurship, the stigma of jamu being bitter and less innovative, the difficulty of entrepreneurship using its own brand, and the lack of good service in the partnership business, the idea arose to establish a jamu partnership business under the name PT OAM. In accordance with long-term financial goals, showing an increase in company assets from the first year to the fifth year. The income statement shows that the company is able to increase profits from year to year. Meanwhile, cash flow shows that income can cover all costs from operating, investing and financing activities. After calculating the investment feasibility analysis shows that PT OAM is feasible to be realized because of the faster rate of return on investment. Calculation of liquidity, solvency and profitability analysis shows that the company is able to pay shortterm and long-term debt and has the ability to increase profits from year to year.

\section{Acknowledgement: None}

\section{Conflict of Interest: None}

\section{Source of Funding: None}

\section{REFERENCES}

1. Dror, S., \& Barad, M. (2006). House of Strategy (HOS): from strategic objectives to competitve priorities. International Journal of Production Research, 44(18-19), 38793895.

2. Fred R. David. (2012). Strategic Management and Business Policy Globalization, Innovation and Sustainability Fifteenth Edition. In Foreign Affairs (Vol. 91).

https://doi.org/10.1017/CBO978110741532 4.004 .

3. Gansel, B. B. (2005). Toward a Framework of Financial Planning in The New Venture Creation. Magdeburg, Germany.

4. Kusuma, A., Syah, T. Y., Indradewa, R., \& Fajarwati, D. (2021). Implementation of Financial Strategy Business Plan Arena Corner. 4(07), 86-89.

5. Kwarti, C., Marsiwi, K., Yanuar, T., Syah, R., Pusaka, S., \& Indradewa, R. (2019). Investment Feasibility Analysis in Financial Aspects of Startup Business In Lifestyle Combining Barbershop And Coffee shop Over PT. Jeeva Work Corporation. Journal 
Noer Rachman Chakim et.al. Financial planning: applications to business startups "jamu partnership" in Indonesia.

of Multidisciplinary Academic, 3(4), 97100. Retrieved from http://www.kemalapublisher.com/index.php /JoMA/article/view/398.

6. Oprea, A. (2010). The importance of investment feasibility analysis, Journal of Property Investment \& Finance, Vol. 28 No. 1, pp. 58-61. https: doi.org 10.110814635781011020038.pdf.

7. Prihambodo, F. P., Yanuar, T., Syah, R., Indradewa, R., \& Fajarwati, D. (2020). Investment Feasibility Analysis in Financial
Aspects of Noor Halal Minimarket Business Development Over Islamic Schools. Journal of Multidisciplinary Academic, 04(03), 190-193.

How to cite this article: Chakim NR, Indradewa $R$, Syah TYR et.al. Financial planning: applications to business startups "jamu partnership" in Indonesia. International Journal of Research and Review. 2021; 8(8): 483-487. DOI: https://doi.org/10.52403/ijrr.20210865

\section{ATTACHMENTS}

Attachment 3.1 Revenue Plan (Rp.000)
\begin{tabular}{|l|c|c|c|c|c|}
\hline \multicolumn{1}{|c|}{ Sales Target } & Year 1 & Year 2 & Year 3 & Year 4 & Year 5 \\
\cline { 2 - 6 } & Amount & Amount & Amount & Amount & Amount \\
\hline Partnership package & & & & & \\
\hline - Package C OAM 1 & 833,000 & $2,091,000$ & $3,281,000$ & $6,562,000$ & $9,843,000$ \\
\hline - Package C OAM 2 & 754,000 & $1,664,000$ & $3,484,000$ & $6,968,000$ & $10,452,000$ \\
\hline - Package C OAM 3 & 300,000 & $2,750,000$ & $3,500,000$ & $7,000,000$ & $10,500,000$ \\
\hline - Package C OAM 4/Custom & 200,000 & $1,500,000$ & $5,000,000$ & $10,000,000$ & $15,000,000$ \\
\hline & $2,087,000$ & $8,005,000$ & $15,265,000$ & $30,530,000$ & $45,795,000$ \\
\hline Sales Product & & & & & \\
\hline - Sales Product & 174,460 & $3,006,080$ & $8,188,640$ & $18,339,040$ & $34,729,740$ \\
\hline & $2,261,460$ & $11,011,080$ & $23,453,640$ & $48,869,040$ & $80,524,740$ \\
\hline Sales Discount & 0 & $(350,429)$ & $(791,057)$ & $(1,680,202)$ & $(2,881,362)$ \\
\hline Total Revenue & $2,261,460$ & $10,660,651$ & $22,662,583$ & $47,188,838$ & $77,643,378$ \\
\hline
\end{tabular}

Attachment 3.2 Capital Expenditure (Rp.000)
\begin{tabular}{|r|l|r|r|r|r|r|}
\hline No & \multicolumn{1}{|c|}{ Assets } & Year 1 & Year 2 & Year 3 & Year 4 & Year 5 \\
\hline 1 & Vehiches & & 380,000 & & & \\
\hline 2 & Office Equipment & 92,450 & & & & 97,073 \\
\hline 3 & Training Equipment & 10,200 & & & & 10,710 \\
\hline 4 & IT Equipment & 321,200 & & & & 337,260 \\
\hline \multicolumn{2}{|c|}{ Total } & 423,850 & 380,000 & 0 & 0 & 445,043 \\
\hline
\end{tabular}

\begin{tabular}{|c|c|c|c|c|c|c|c|}
\hline \multicolumn{8}{|c|}{ enditure (Rp.00 } \\
\hline No & Description & Year 0 & Year 1 & Year 2 & Year 3 & Year 4 & Year 5 \\
\hline 1 & Building Renovation & 150,000 & & & & & \\
\hline 2 & Licensing & 12,000 & & & & & \\
\hline 3 & Cafe Display & 25,000 & & & & & \\
\hline 4 & Consultant Fee & 50,000 & & & & & \\
\hline 5 & Electricity Expense & & 36,000 & 75,600 & 79,380 & 83,349 & 87,516 \\
\hline 6 & Water Expense & & 15,000 & 18,900 & 19,845 & 20,837 & 21,879 \\
\hline 7 & Office Telephone Expense & & 24,000 & 25,200 & 26,460 & 27,783 & 29,172 \\
\hline 8 & Internet Expense & & 6,000 & 6,300 & 6,615 & 6,946 & 7,293 \\
\hline 9 & Cell Phone Pulse Expense & & 2,000 & 3,150 & 3,308 & 3,473 & 3,647 \\
\hline 10 & Office supplies Expense & & 12,000 & 12,600 & 13,230 & 13,892 & 14,586 \\
\hline 11 & Office Household Expenses & & 6,000 & 6,300 & 6,615 & 6,946 & 7,293 \\
\hline 12 & Unlimited Zoom & & 2,000 & 2,100 & 2,205 & 2,315 & 2,431 \\
\hline 13 & $R \& D$ Expense & & 20,000 & 42,000 & 44,100 & 46,305 & 48,620 \\
\hline 14 & IT Expense & & 60,000 & 63,000 & 66,150 & 69,458 & 72,930 \\
\hline 15 & Shipping Expense & & 45,229 & 220,222 & 469,073 & 977,381 & $1,610,495$ \\
\hline 16 & Vehicle maintenance costs & & 12,000 & 12,600 & 13,230 & 13,892 & 14,586 \\
\hline 17 & Vehicle Insurance Expense & & 0 & 2,380 & 2,380 & 2,380 & 2,380 \\
\hline 18 & Vehicle Costs (gasoline, tolls) & & 0 & 63,000 & 66,150 & 69,458 & 72,930 \\
\hline 19 & Official travel Expenses & & 18,000 & 18,900 & 19,845 & 20,837 & 21,879 \\
\hline 20 & Security Expense & & 60,000 & 126,000 & 132,300 & 138,915 & 145,861 \\
\hline 21 & Office Rent Expense & & 80,000 & 80,000 & 88,200 & 92,610 & 97,241 \\
\hline & Warehouse Rent Expe & & 0 & 80,000 & 84,000 & 88,200 & 92,610 \\
\hline & Total & 237,000 & 398,229 & 858,252 & $1,143,085$ & $1,684,975$ & $2,353,350$ \\
\hline
\end{tabular}

\begin{tabular}{|c|c|c|c|c|c|}
\hline \multicolumn{6}{|c|}{ Attachment 3.4 Capital Plan (Rp.000) } \\
\hline Shareholders & Unit & $\%$ & $\begin{array}{c}\text { Stock } \\
\text { Value/Unit }\end{array}$ & Total & Description \\
\hline Mrs. ES & 600 & $10.34 \%$ & 1,000 & 600,000 & Founder \\
\hline Mr. NC & 600 & $10.34 \%$ & 1,000 & 600,000 & Founder \\
\hline Mr. AS & 600 & $10.34 \%$ & 1,000 & 600,000 & Founder \\
\hline Mr. SY & 600 & $10.34 \%$ & 1,000 & 600,000 & Founder \\
\hline Sub total & 2,400 & $41.38 \%$ & & $2,400,000$ & \\
\hline Other investors & 3,400 & $58.62 \%$ & 1,000 & $3,400,000$ & Angel Investor \\
\hline Total & 5,800 & $100.00 \%$ & & $5,800,000$ & \\
\hline
\end{tabular}

